\title{
QUANTIFICATION OF THE NATURAL FACTORS' IMPACT EFFECTIVENESS ON ENVIRONMENTAL HAZARDS - SLOPE MOVEMENTS IN THE FLYSCH AREAS OF THE KYSUCE REGION
}

\author{
MÁRIA BARANČOKOVÁ, ZDENA KRNÁČOVÁ, SILVIA CHASNÍKOVÁ
}

Institute of Landscape Ecology, Slovak Academy of Sciences, Štefánikova 3, P.O. Box 254, 81499 Bratislava, Slovak Republic; e-mail: maria.barancokova@savba.sk, zdena.krnacova@savba.sk, silvia.chasnikova@savba.sk

\begin{abstract}
Barančoková M., Krnáčová Z., Chasníková S.: Quantification of the natural factors’ impact effectiveness on environmental hazards - slope movements in the flysch areas of the Kysuce region. Ekológia (Bratislava), Vol. 36, No. 3, p. 197-213, 2017.

The flysch areas belong to the territories with highest occurrence of landslides in Slovakia. Almost $67 \%$ of all landslides in Slovakia take place within the Carpathian flysch. It is a type of slope deformation that responds sensitively to the quality of individual factors that form the landscape and to the change in natural conditions. The occurrence of various geodynamic phenomena can be understood as a geological barrier that reduces or inhibits the use of natural environment and negatively affects the life of society and territorial development. In this paper, we evaluate the statistical significance of selected natural factors of the landscape in relation to the occurrence of unstable slopes in the Kysuce region. In addition, we also evaluated the expansion of unstable slopes in individual landscape factors. Significant linkages between the variables' hydrogeological base_sandstones with thin clay layers (HB_s) and geological-substrate complex_loamy wastes to loamy-stony debris on sandy conglomerates (GSC_sc) $(\mathrm{R}=0.95, \mathrm{p}=0.002)$ and secondary significant linkages between the variables soil type: Dystric Cambisols ( $\left.S \_C M d\right)$ and HB_s $(\mathrm{R}=0.40$, $\mathrm{p}=0.002$ ) (Klokočov and Zákopčie cadastres) were observed. Significant correlation of variables within the areas with unstable slopes was also observed between hydrogeological base_sandy flysch (HB_sf) and geological-substrate complex_loamy wastes on flysch stones (GSC_fs) (R=0.81, $\mathrm{p}=0.002)$ (Nová Bystrica and Kysucké Nové Mesto cadastres). The most unstable slopes occur in Nová Bystrica cadastre (34.62\% of the area) and in the Klokočov cadastre (28.25\% of the area). The inclination of slopes (especially slopes above $12^{\circ}$ ) plays an important role within the unstable slopes. Slopes with steep inclination cover up to $81.45 \%$ of the cadastral area of Nová Bystrica, of which almost $1 / 3$ are unstable slopes.
\end{abstract}

Key words: slope movements, statistical methods, flysch area, natural factors.

\section{Introduction}

The Carpathian flysch region forms a contiguous belt at the outer edge of the Western Carpathian Mountains and extends through extensive spurs to the inner Carpathian Mountains. The rock complexes of the flysch formation have a dominant position, of which the most 
widespread is the rhythmic-bedded clayey-sandstone flysch. The flysch territory belongs to the areas with the highest landslide occurrences in Slovakia. Almost 67\% of all landslides in Slovakia take place within the Carpathian flysch. It is a type of slope deformation that responds sensitively to the quality of individual factors that make up the landscape and to the natural condition changes. The occurrence of various geodynamic phenomena can be understood as a geo-barrier that reduces or totally obviates the use of natural environment and negatively affects the life of society and territorial development.

Most of the territory in Kysuce region is built by Paleogene complexes of the fine-rhythmic flysch, which are a good prerequisite for forming of strong deluvial covers. These can activate slope movements under suitable hydrogeological conditions, after large-scale solifluction processes with the formation of shear surfaces with pre-Quaternary subbasement. Unstable slopes in Kysuce region cover almost $235 \mathrm{~km}^{2}$.

As reported by Húska (1981), the landslide occurrence is caused by the breach of balance between stabilizing forces (cohesion) and gravity. Changes in the balance can cause inclination change, surface load, slope base violation, increased content of soil water, increased amount of water and water leakage on the impermeable bedrock.

An important task in determining the causes of slope movements is the evaluation of conditions in which they happen and to test the selection of presumed correlating factors responsible for their occurrence. The geological, geomorphological, hydrogeological, hydrological and climatic conditions can be included among the factors responsible for the formation and development of slope movements. Factors that cause or affect changes in natural conditions (slope changes, changes in the slope height, changes in the water content, groundwater flow, frost activity, weathering, vegetation cover changes, etc.) have natural and anthropogenic character. Listed factors combine together, while water activity is always present and penetrates into the permeable slope layers, softens the soil and forms a sliding surface on the impermeable bedrock, on which the overlying layers slide with their own weight.

In some mountain areas, landslides are termed as dominant erosive processes influenced by human activities such as road construction and changes in the use of soil (Morgan, 2005; Preuth et al., 2010). Fine-grained sedimentary rocks (marl and clay shale) condition the genesis of soils with high erodibility, which are prone to landslides (Eberhardt et al., 2005). Ahmadi, Esfandarani (2002) reported that marls without a vegetation cover occurring in areas with 20$40^{\circ}$ slope inclination were prone to landslips. Water retention in soil is strongly subordinated to the percentage content of clay, when the content of water in soil can be increased up to 210 $\mathrm{mm} / \mathrm{m}$ in the soil profile (Hazelton, Murphy, 2007; Ondr et al., 2016). High stability of the soil aggregate protects the soil from erosion. On the contrary, low aggregation of soil particles is a characteristic feature of the soils with unstable structure, low permeability and low infiltration, which contributes to the occurrence of tubular pores in clay soils and these soils are more prone to the formation of slope deformations. Diaz et al. (2006) derived the inverse relationship between the stability of soil aggregate and the density of tubular structure in the clay soil. Soils with low aggregate stability are susceptible to erosion. When the stability of soil aggregate is reduced, soil erodibility can be increased (Blanco, Lal, 2008; Heshmati et al., 2011).

Geological structure (lithology, seismic-tectonic ratios and structural ratios), geomorphological conditions and the character of the georelief (morphometric characteristics, in 
particular, the slope inclination), hydrogeological-climatic and related hydrological conditions of the area, as well as, anthropogenic factors represented by inappropriate use of the landscape (Skokanová et al., 2016; Špulerová et al., 2016) can be considered as relevant factors reflecting the favourable conditions for the occurrence of landslides.

The most important publications dealing with landslide hazards are Carrara et al. (1991, 1995), Klimeš (2007), Metelka, Kycl (2007), Havlín et al. (2009) and so on. In the Slovak Republic, the evaluation of landslide hazards has been recently dealt with by various authors, for example, Pauditš, Bednarik (2002, 2006), Bednarik et al. (2005), Magulová (2009) and so on. Paudiš et al. (2005) evaluated 11 input parameters derived from the geological conditions of the area, climatic and hydrological conditions, morphometry of the georelief and current landscape structure. The evaluation was processed by the bivariate method with the weight of the parameter as a whole.

In this paper, we evaluate the statistical significance of the selected natural factors of the landscape in relation to the occurrence of unstable slopes in the Kysuce region. We also evaluated the abundance of individual landscape factors and unstable slopes in selected cadastral areas.

\section{Study area}

We have selected four regions, which characterize the diversity of abiotic and biotic components of the whole studied area. The selected areas are: Klokočov, Zákopčie, Nová Bystrica and Kysucké Nové Mesto (Fig. 1). Selected areas belong to three regions according to the

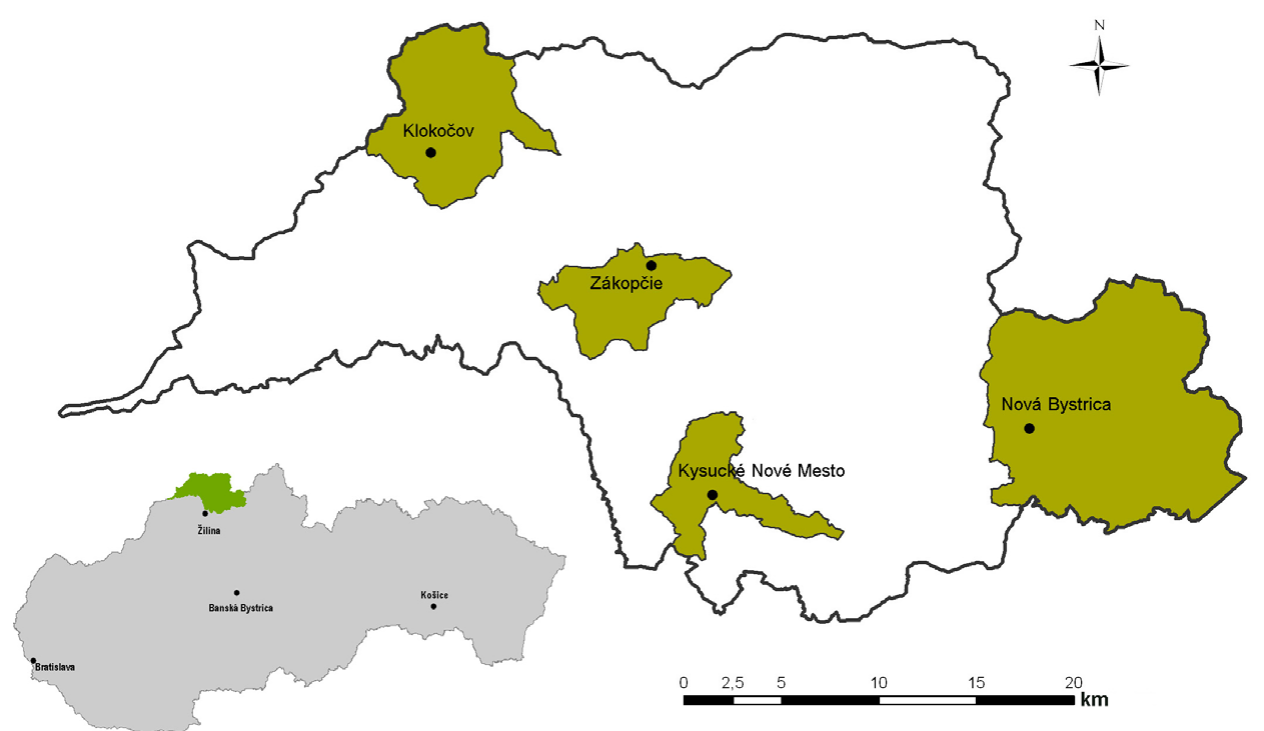

Fig. 1. Location of the study sites. 


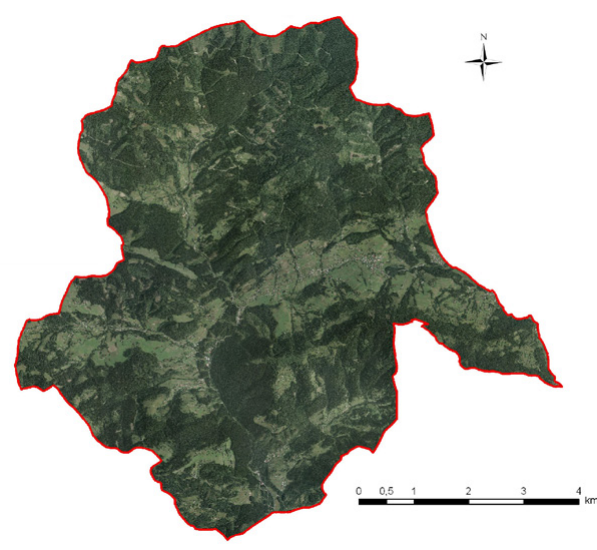

Fig. 2. Klokočov village.

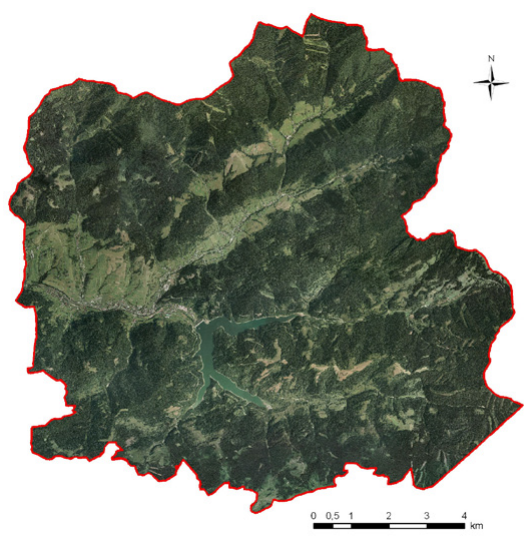

Fig. 3. Nová Bystrica village.

geomorphological units of the Slovakia (Mazúr, Lukniš, 1986): Stredné Beskydy (units Kysucká vrchovina highlands, Kysucké Beskydy Mts., Podbeskydská vrchovina highlands, Oravská Magura Mts. and Oravské Beskydy Mts.), Západné Beskydy (units - Moravskosliezske Beskydy Mts. and Turzovská vrchovina highlands) and Slovensko-moravské Karpaty (unit - Javorníky Mts.).

\section{Klokočov village}

The cadastre of Klokočov village $\left(51 \mathrm{~km}^{2}\right)$ (Figs 1 and 2) lies in the Turzovská vrchovina highlands (3,523 ha) and Moravsko-Sliezske Beskydy Mts. (1 588 ha), in the north-western part of Kysuce region. It has an upland to mountainous character with an altitude of 508 to $1.061 \mathrm{~m}$ a. s. l., with predominance of slopes with 12 to $17^{\circ}$ (36.3\% of the cadastral area). Slopes with inclination from 7 to $12^{\circ}$ cover $28.9 \%$ of the area and slopes with inclination from 17 to $25^{\circ}$ cover an area of $27.3 \%$. The territory belongs to the Predmieranka river basin, which is an important inflow of the Kysuca river. The cadastre is built mainly by the Istebna Formation (quartzy-arcose and greywacky sandstones to conglomerates) and the sandy facies of the Ráztoky Member. Most of the soils are dystric cambisols (70.6\% of the cadastral area) and skeli-eutric cambisols (10.9\%). Coniferous forests cover $64 \%$ of cadastral area, meadows and pastures cover $14 \%$, permanent crops $9 \%$ and arable land $1 \%$ and so on.

\section{Nová Bystrica village}

Cadastre of the Nová Bystrica village has an area of $125 \mathrm{~km}^{2}$ (Figs 1 and 3). This village has been joined by the municipalities of Riečnica and Harvelka, which had been flooded due to the construction of a water tank for drinking water, and now belongs to the largest villages in Slovakia. The whole territory belongs to the Bystrica river basin. It is located in five geomorphological units. The largest area covers Kysucká vrchovina highlands (9 038 ha) and Kysucké Beskydy Mts. (2 463 

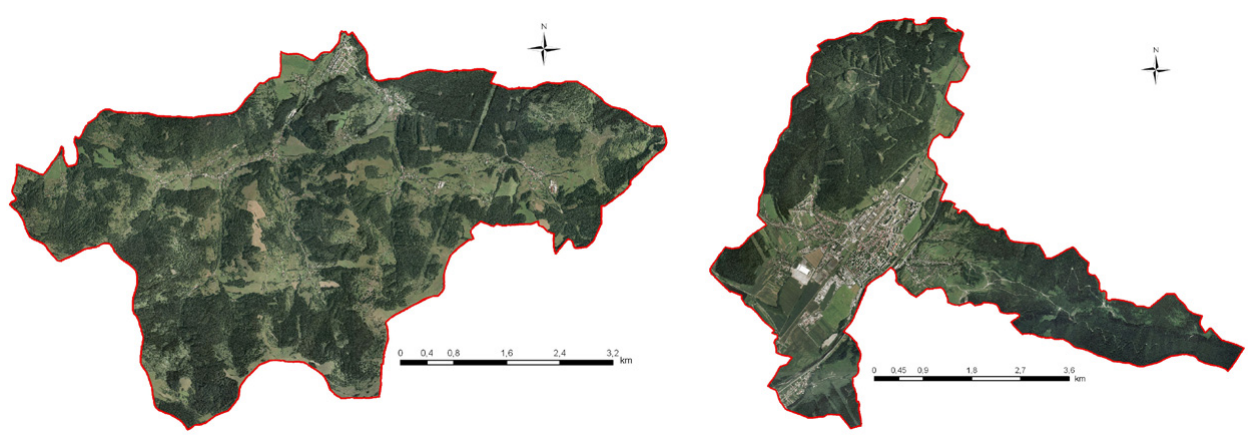

Fig. 4. Zákopčie village.

Fig. 5. Kysucké Nové Mesto city.

ha). Podbeskydská vrchovina highlands, Oravská Magura Mts. and Oravské Beskydy Mts. cover $1033 \mathrm{ha}$. The territory has an upland to mountainous character with an altitude of $490 \mathrm{~m}$ to 1226 $\mathrm{m}$ a.s.l. Slopes with inclination from 17 to $25^{\circ}(42.1 \%)$ and from 12 to $17^{\circ}(32.5 \%)$ cover most of the area. This area is built by sandstone flysch consisting mainly of Bystrica Member (Bystricatype claystone, arkosic sandstones) and Kýčera Member (greywacke sandstones, locally shales). Eutric cambisol is the most widespread and covers $49.4 \%$ of the cadastral area and dystric cambisols cover $18.5 \%$ of the area. Coniferous forests cover most of the area with $58.4 \%$. The meadows and pastures cover $16.3 \%$ of the area and the arable land only $1 \%$.

\section{Zákopčie village}

The cadastre of Zákopčie village $\left(29.6 \mathrm{~km}^{2}\right)$ extends in the north-eastern part of the Javorníky Mts. (Figs 1 and 4). Javorníky are one of the geomorphological units of this territory. The territory has an upland character with an altitude of 470 to $875 \mathrm{~m}$ a.s.l. Slopes with inclination of 12 to $17^{\circ}$ cover half of the territory (50.3\%). The territory is drained by the Zákopčeiansky and Rakovský creeks. The area is predominantly built by a normal flysch, which is formed by Vsetín Member (Bystrica-type claystones, sandstone with glauconite, arkosic sandstones and conglomerates) and Zlín Formation (claystones, sandstones, sandstone with glauconite). The most widespread soil subtype is cambisol, which occurs on $40.4 \%$ of the territory, and $38.2 \%$ of the territory cover skeli-eutric cambisols. Almost $42 \%$ of the territory is covered by coniferous forests. Meadows and pastures cover $23 \%$ and arable land only $0.8 \%$ of the area.

\section{Kysucké Nové Mesto city}

Kysucké Nové Mesto cadastre $\left(26.4 \mathrm{~km}^{2}\right)$ is situated in Javorníky Mts. (2 022 ha) and Kysucká vrchovina Mts. (620 ha) (Figs 1 and 5). The territory has upland and partly mountainous character with an altitude from 340 to $999 \mathrm{~m}$ a.s.l. Slopes ranging from 12 to $17^{\circ}$ and from 17 to $25^{\circ}$ cover equal sizes of the area (22.5\% of the cadastral area). The territory is drained by the Povinský creek and the Kysuca river. In this area, sandstone flysch prevails (44.9\% of 
the territory) and is formed by Bystrica Member (44.9\% of the area). Floodplains and terraces formed by sandstones and sandy gravel cover $18.6 \%$ of the area and the Klippen belt (Posidonia and Supra-Posidonia beds, and Pieniny Limestone Formation) extends to the territory with $10.2 \%$. The most widespread is the eutric cambisol (32.2\%), then stagnic cambisol (29.4\%) and eutric fluvisol (25.2\%). Coniferous forests cover the largest area (39.2\%), meadows and pastures following with (14.8\%). Arable land has a 7.5\% representation.

\section{Material and methods}

We proceeded from the database of Landscape Ecological Complexes (LEC types), which are vector representation of synthetic units expressing relevant properties of the abiotic elements of the landscape together with the landscape cover elements. We compiled a data matrix from the selected presumed correlation parameters that are in the form of vector layers. Data matrix was evaluated using the multidimensional statistical method in program CANOCO.

We obtained altogether 52054 samples of LEC and unstable slopes occurrence from the area of Kysuce region (Žabková et al., 2003; Šimeková et al., 2006). For purpose of our analysis, we chose four most characteristic cadastres, which gave us the final number of 12716 samples for our analysis (Klokočov - 2680, Kysucké Nové Mesto - 1074, Nová Bystrica - 7608, Zákopčie - 1354). Analysis and final graphs were made in program CANOCO 5.0 (ter Braak, Šmilauer, 2012). The indirect gradient analysis - PCA (principal component analysis) was used to see the variation in landscape factors. The RDA (redundancy analysis) with the forward selection command was used to evaluate the interaction between individual factors and to determine the landscape parameters that best explain the variance of the data set (Annex 1). We used 499 permutations for the RDA analysis to calculate the correlation coefficients $(\mathrm{p}=0.002)$. The parameters listed in Tables 1-5 were used as categorical variables. Parameters -slope inclination, depth of groundwater levels, depth of soil, and soil skeleton are semi-quantitative and were transformed using corresponding ordinal levels (Šmilauer, Lepšs, 2014). In the output ordination graph, we can interpret the proximity of two points (co-ordinates of individual factors).

Overview of selected parameters in the form of LEC vector layers:

- Morphographic-morphometric types of relief - the layer was created by digitizing the underlying layers with respect to the morphographic types and positional forms of the relief and so called elementary forms of georelief - morphotopes were bounded (Table 1).

- Slope inclination (in degrees) - represents a continuous field of altitude gradients, it is a key morphometric parameter determining the instant intensity of gravitational geomorphological processes. The slope inclination was divided into the following categories: $1-(0-1>, 2-(1-3>, 3$ - (3-7>, 4 - (7-12>, 5 - (12-17>, 6 - (17-25>, 7 (25-35>, 8 - (35-90>.

- Hydrogeological base (HB) - a hydrogeological complex with a rocky character (Malík et al., 2007), (Table 2).

- Geological-substrate complex (GSC) - a layer of basic genetic types of quaternary sediments (quaternary deposits typology) (Table 3).

- Depth of groundwater levels below the surface (DGL) - data on groundwater levels were obtained from hydrogeological borehole. A correlation of data with morphometric relief characteristics was performed for the outlying areas. In
T a b le 1. Morphographic-morphometric types of relief (MM).

\begin{tabular}{|l|l|}
\hline Legend & Definition \\
\hline MM_ft & flat top \\
\hline MM_ct & cupola top \\
\hline MM_r & ridge \\
\hline MM_wf & wide river-floodplain \\
\hline MM_nf & narrow floodplain of mountain streams \\
\hline MM_ac & alluvial cone \\
\hline MM_ds & downward slope \\
\hline MM_s & saddle \\
\hline MM_bwb & bottom of the water basin \\
\hline MM_d & dell \\
\hline MM_bsv & bottom of slope valley \\
\hline MM_sv & slope valley \\
\hline MM_ts & transport slope \\
\hline MM_p & plateau \\
\hline MM_g & gully to ravine \\
\hline
\end{tabular}


areas affected by hydrogeological research, values were extrapolated by interpolation algorithm (Malík et al., 2007). The groundwater levels were divided into the following categories (in $\mathrm{m}$ ): up to $1 ; 1.0-1.5 ; 1.5-2.0$; 2.0 - 3.0; 3.0 - 4.0; 4.0 - 6.0; 6.0 - 8.0; 8.0 - 10.0; 10.0 - 12.0; 12.0 - 15.0; 15.0 - 20.0; 20.0 - 25.0; 25.0 - 30.0; $30.0-50.0 ; 50.0-100.0$.

- Soil subtype (S) - a complex of soil units in terms of the soil subtype, according to the Societas pedologica slovaca, (2014), (Table 4).

- Grain Size (GS) - a soil grain layer was created on the basis of input data contained in soil probes (grain fractions - sand, silt, clay) and maps of forest soils. Multiple linear regression and interpolation in a geographically homogeneous environment with sufficient density of the input dot field was used. The grain size was divided into the following categories: Gs_sc (sandy-clay), Gs_l (loamy), Gs_sl (silty-loam), Gs_scl (sandy-clayeyloamy) and Gs_cl (clayey-loam).

- Depth of soil (in m) - divided into categories: up to $0.3 \mathrm{~m}$ (shallow soils), 0.3-0.6 $\mathbf{m}$ (medium deep soils) and more than $\mathbf{0 . 6} \mathbf{~ m}$ (deep soils).

- $\quad$ Soil skeleton (in \%) - divided into categories: up to $\mathbf{1 0 \%}$ (skeleton-free), $\mathbf{1 0 - 2 5 \%}$ (low skeletal soils), $\mathbf{2 5 - 5 0 \%}$ (medium skeletal soils) and over $\mathbf{5 0 \%}$ (heavily skeletal soils).

- $\quad$ Landscape cover (LC) - represents a materialized projection of natural spatial characteristics as well as the current use of the landscape; its presence on the surface of Earth is mainly differentiated by its appearance and morpho-structural properties (Table 5).

- Unstable slopes (Fig. 6) - data were processed on the basis of outputs in Žabková et al. (2003) and Šimeková et al. (2006), which are based on the databases and field mapping.

T a b l e 2. Hydrogeological base (HB).

\begin{tabular}{|l|l|}
\hline Legend & Definition \\
\hline HB_sd & slope debris \\
\hline HB_tc & debris cones and talus cones \\
\hline HB_ld & loamy-stony and bouldery deposits of landslides deposition \\
\hline HB_dc & loamy-stony debris cones \\
\hline HB_ac & loamy, sandy, gravelly alluvial cones \\
\hline HB_t & sand, sandy gravel, gravel floodplains and terraces \\
\hline HB_llc & clay, limy clay and marl \\
\hline HB_if & clayey flysch (with predominance of clay, silt, marl) \\
\hline HB_nf & normal flysch (clay/marl, silt, sandstones) \\
\hline HB_sf & sandy flysch (prevalence of sandstones) \\
\hline HB_cf & conglomerate flysch (prevalence of conglomerates) \\
\hline HB_s & sandstones with thin clay layers \\
\hline HB_l & limestones (siliceous, marlaceous, sandy, etc.), radiolarites \\
\hline
\end{tabular}

T a b le 3. Geological-substrate complex (GSC).

\begin{tabular}{|l|l|}
\hline Legend & Definition \\
\hline GSC_as & loamy-gravelly to gravelly alluvial sediments \\
\hline GSC_ts & loamy-gravelly terrace sediments \\
\hline GSC_ps & loamy-gravelly to gravelly proluvial sediments \\
\hline GSC_ds & loamy-gravelly deluvial sediments \\
\hline GSC_cs & gravelly-boulder colluvial sediments \\
\hline GSC_1 & landslides \\
\hline GSC_css & loamy wastes on consolidated clayey-silty stones \\
\hline GSC_fs & loamy wastes on flysch stones \\
\hline GSC_sc & loamy wastes to loamy-stony debris on sandy conglomerates \\
\hline
\end{tabular}


T a b le 4 . Soil subtype (S).

\begin{tabular}{|l|l|}
\hline Legend & Definition \\
\hline S_LPe & Eutric Leptosols \\
\hline S_LPk & Rendzic Leptosols \\
\hline S_CMe & Eutric Cambisols \\
\hline S_CMs & Skeli-Eutric Cambisols \\
\hline S_CMd & Dystric Cambisol \\
\hline S_CMj & Stagnic Cambisols \\
\hline S_PZh & Haplic Podzol \\
\hline S_GLe & Eutric Gleysols \\
\hline S_FLe & Eutric Fluvisol \\
\hline
\end{tabular}

T a b le 5. Landscape cover (LC).

\begin{tabular}{|l|l|}
\hline Legend & Definition \\
\hline LC_r & residential area \\
\hline LC_ia & industrial, commercial and transport areas \\
\hline LC_al & arable land \\
\hline LC_pc & permanent cultures \\
\hline LC_mp & meadows and pastures \\
\hline LC_df & deciduous forests \\
\hline LC_mf & mixed forests \\
\hline LC_cf & coniferous forests \\
\hline LC_f & other forests \\
\hline LC_asv & areas with sparse vegetation \\
\hline LC_wa & water areas \\
\hline
\end{tabular}

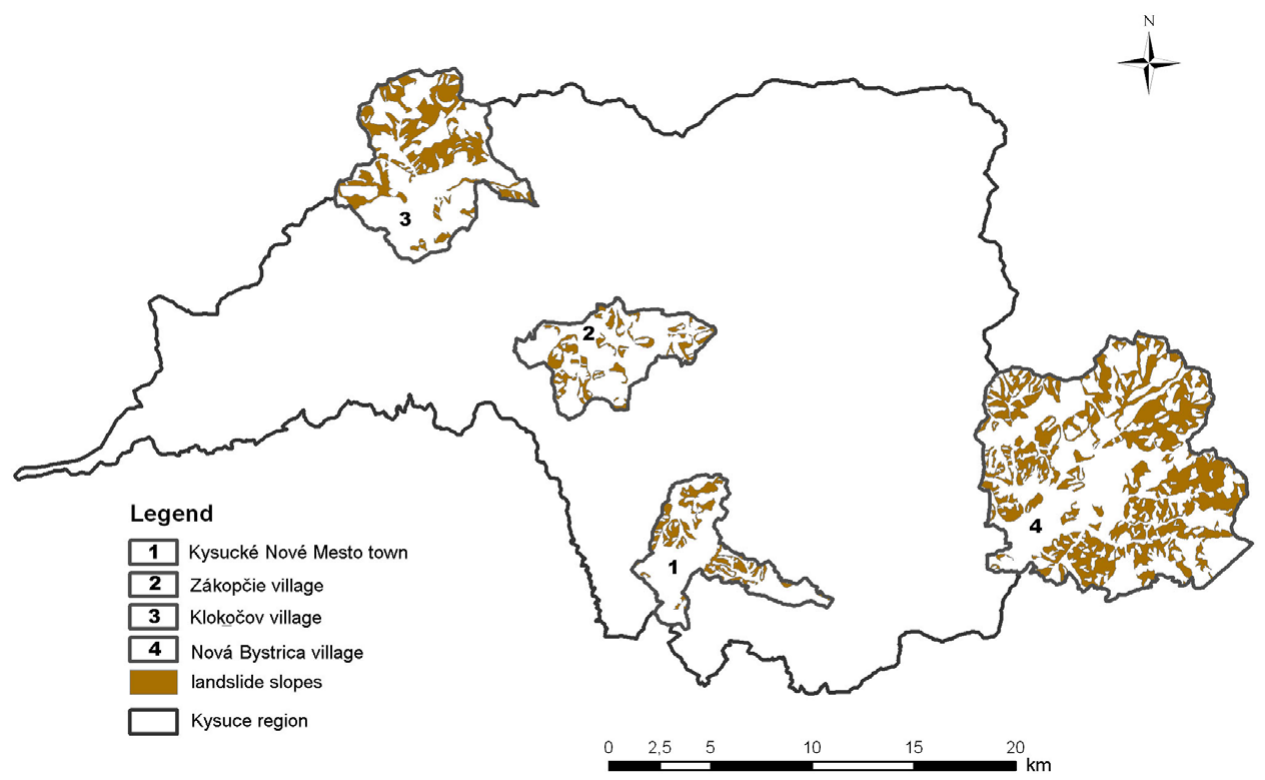

Fig. 6. Occurrence of unstable slopes in the individual cadastral areas.

\section{Results and discussion}

a) Assessment of the correlation linkages between selected landscape factors and unstable slopes

Significant linkages between the variables HB_s and GSC_sc $(\mathrm{R}=0.95, \mathrm{p}=0.002)$ and secondary significant linkages between the variables $\mathrm{S} \_\mathrm{CMd}$ and $\mathrm{HB} \_\mathrm{s}(\mathrm{R}=0.40, \mathrm{p}=0.002)$ were con- 
firmed (Fig. 7). Sandstones with thin clay layers, which form loamy wastes with dystric cambisol occur in most areas with unstable slopes in the Klokočov cadastre and partly in Zákopčie cadastral area. Significant correlation of variables in areas with unstable slopes was also observed between HB_sf and GSC_fs $(\mathrm{R}=0.81, \mathrm{p}=0.002)$ (Fig. 7). It is mainly the area built by the sandstone flysch, which makes loamy wastes with typical cambisol. These are mainly territories in the cadastral areas of Nová Bystrica and Kysucké Nové Mesto. The rock complex in sandstone development is the main collector of groundwater, characterized by crack-intergrain permeability and the drainage of this complex is considerably variable. These complexes are made by rocks with low permeability. Unlike this complex, rocks in sandstone-clay development are characterized by rhythmic alternation of sandstones and clay (or prevalence of sandstones in some parts of the formation), that is, rocks with aquiferous properties with isolators that limit the groundwater circulation in the complex. The clayey substrate is poorly permeable and the most precipitation water flows over the surface, following with more intensive erosion development (especially in deforested areas) with subsequent formation of landslips.

Significant linkage was also calculated between the variables GSC_cs and HB_tc ( $R=0.90$, $\mathrm{p}=0.002$ ). It is a significant interconnection of the occurrence of gravel-boulder colluvial sediments with periglacial stony-sandstone blocks of debris cones and streams with high occurrence of rock falls and stone seas. Significant correlation coefficient $R=0.89, p=0.002$ was recorded between variables GSC_as and HB_t. These are mainly gravelly-loam and gravel alluvial deposits with sand, sandy gravel and fine to rough alluvial beds and low terraces covered with floodplain clayey loam, sandy loam, loamy sands and loamy gravels. These are rocks and pedogenic substrates which have high groundwater levels in their profile. Due to groundwater flow and climatic factor such as frost, unfavourable geodynamic phenomena arise in these areas as well. This is also confirmed by significant linkages between GSC_as and S_FLe ( $R=0.78, p$ $=0.002$ ). It is a connection of gravelly loam and gravel alluvial deposits with sand and sandy gravel with occurrence of fluvisols. There is a high groundwater level with a high retention capacity and possible occurrence of geodynamic phenomena. The weathering of flysch rocks is inhomogeneous and results from the lithological units' character. Lute and considerable part of the bedrock are carried away from the weathering layer of sandstones by weathering, making them more porous and more susceptible to disintegration. Claystones are more durable in resisting aerial alteration, and they are mostly weathered by the influence of repeated soaking and drying. The different degrees of resistance of flysch complexes to erosion depends on the substance inhomogeneity and the different behaviour of rocks in the weathering process. The sandstone and clay layers' alternation leads to selective erosion and therefore to significant terrain modelling. Sandstone complexes fairly resist erosion and form ridges. Formations with a lutaceous content and especially a finer rhythmicity form depression zones. Stronger tectonic deformation of the formation also conduces the erosion.

A moderately significant correlation with unstable slopes was noticed in the variables of the slope and GSC_fs $(\mathrm{R}=0.29, \mathrm{p}=0.002)$, which play an important role in the landslide areas. Slopes above $12^{\circ}$ predominate within all disasters, which is also a prerequisite for increased landslides. However, we observed a negative correlation between the slope and S_FLe variables, where the correlation coefficient has values $(\mathrm{R}=-0.42, \mathrm{p}=0.002)$. The recorded correlation confirms the occurrence of unfavourable geodynamic processes in the regions with luvisols 
that formed on sands, sandy gravel and fine to rough gravel of the accumulation floodplain bottom or terraces and river floodplains. Based on our work, we can determine the order of significance of the observed factors. The geological substrate complex (GSC) and hydrogeological bedrock (HB) that condition the formation of unstable slopes are significant for the analysed area. Secondary impacts have morphography-morphometric types of relief (MM). The soil subtype (S) is at the border of significance. The impact of anthropogenic activities has not been confirmed because no significant human activity has been mapped in the concerned area. This is also confirmed by the analysis of the landscape cover (LC), where continuous forest stands, meadows and pastures dominate the monitored area.

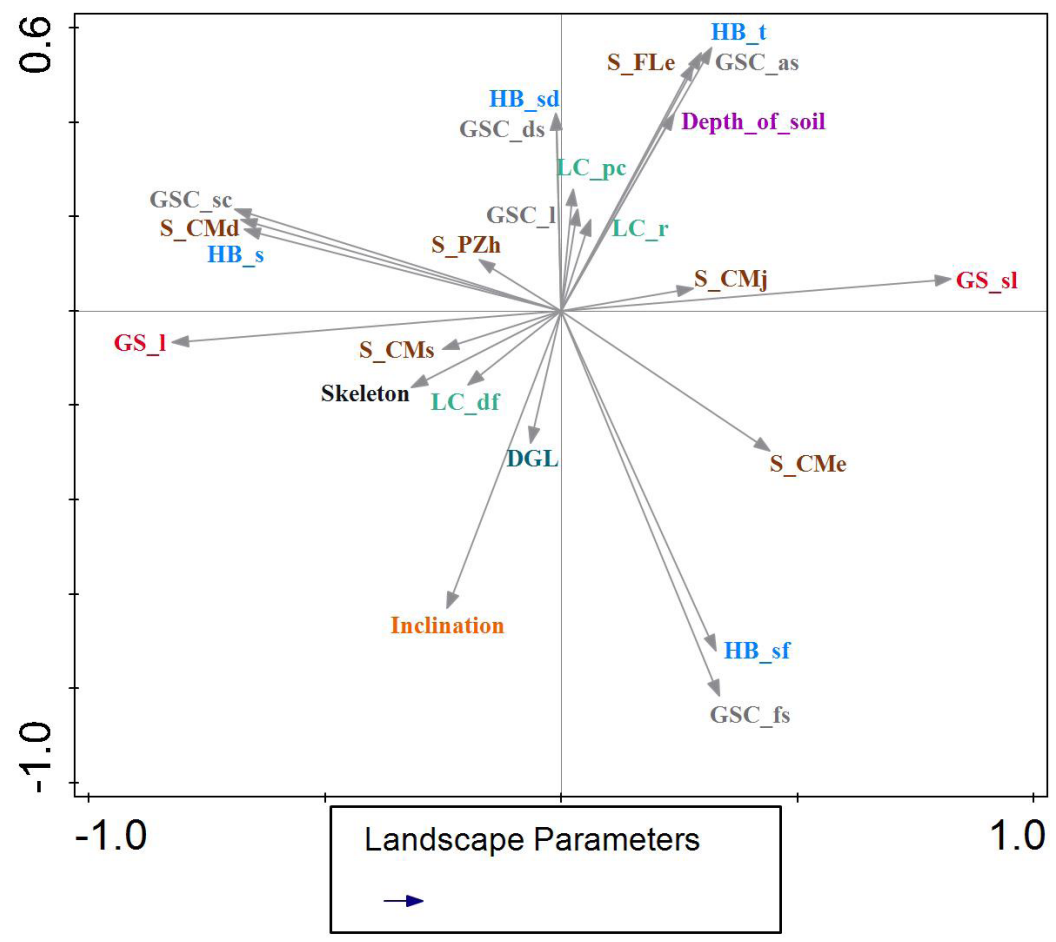

Fig. 7. Ordinal graph showing the dependence of selected landscape factors on selected cadastral areas with unstable slopes.

\section{b) Evaluation of superposition of the selected landscape factors and unstable slopes}

For the assessment, we proceeded from the extension of the given natural factor in the cadastre and from the extension of the unstable slopes occurrence within the area (Table 7). The largest area covered by unstable slopes is in the cadastral areas of Nová Bystrica (34.62\%) and Klokočov (28.25\%). Less coverage is in the cadastral areas of Kysucké Nové Mesto (19.03\%) and Zákopčie 
(16.87\%). We only took into account the factors of the country with the highest occurrence of unstable slopes. The largest representation of the type of relief (MM) factor has the category of transport slope (MM_ts). Within the transport slope category, the most unstable slopes occur in the cadastral areas of Klokočov (29.31\% of the slippery surface within MM_ts), Nová Bystrica (36.16\% of the slippery surface within MM_ts) and Kysucké Nové Mesto (26.11\% of the slip surface within MM_ts). From the total area of cadastres, the unstable slopes cover the largest area $(21.74 \%)$ in Nová Bystrica cadastre, in Klokočov cadastre (17.05\%), in Zákopčie cadastre (12.59\%) and in Kysucké Nové Mesto cadastre (10.75\%) (Fig. 8). In Zákopčie cadastre, there are very unstable gullies and ravens (MM_g), which cover a small area of the cadastre, but the occurrence of unstable slopes on these types of relief is up to $67 \%$ (however, this area is negligible as compared to the total area, only $0.04 \%$ ).

The instability of the area was also evaluated on the basis of slope inclination factor. The inclination of slope plays an important role in unstable slopes. Unstable slopes with inclination between 12 to $17^{\circ}$ prevailed in three cadastres (Table 6). It was Klokočov cadastre, which has $28.04 \%$ of the unstable slopes in this category (it is $10.17 \%$ from the total cadastral area). Zákopčie cadastre has unstable slopes on an area of $17.11 \%$ (they represent $8.61 \%$ from the whole cadastral area) and Kysucké Nové Mesto cadastre has unstable slopes on the area of $35.99 \%$ (it is $8.14 \%$ from the total area of cadastre) (Fig. 8). In the cadastral area of Nová Bystrica there are also slopes with inclination above $35^{\circ}$ and their instability is recorded on $50 \%$ of the area, which is only $0.01 \%$ of the whole territory. This cadastre has the most unstable slopes in the category from 17 to $25^{\circ}$, covering $38.78 \%$ of the territory ( $15.01 \%$ of the whole cadastral area). Slopes above $12^{\circ}$ cover most of the monitored areas, in Nová Bystrica it is up to $81.45 \%$ of the area, in Zákopčie it is $72.67 \%$ of the area, in cadastral area of Klokočov it is $64.25 \%$ of the area and in the cadastral area of Kysucké Nové Mesto it is $53.00 \%$ of the area. The most unstable slopes in this category are represented in the Nová Bystrica cadastre (29.80\% of the area) and in the cadastral area of Klokočov ( $18.52 \%$ of the area).

Another factor - hydrogeological base (Table 6) - has the largest representation in Klokočov cadastral area in HB_s (sandstone with thin clay layers), which covers up to $56.40 \%$ of the cadastral area. Unstable slopes cover $31.39 \%$ of this area (which is $17.70 \%$ of the whole area). Most of the Zákopčie cadastre is built by normal flysch (HB_nf), which occupies $39.07 \%$ of the territory, unstable slopes are on 14.56\% (5.9\% of the whole area). Nová Bystrica and Kysucké Nové Mesto cadastres are mainly built by sandstone flysch (HB_sf), which covers $71.96 \%$ of the Nová Bystrica area with $36.40 \%$ of the unstable slopes $(26.13 \%$ of the total cadastral area) and $44.89 \%$ of the Kysucké Nové Mesto area, of which unstable slopes are on 30.32\% (13.61\% from the total area of the cadastre) (Fig. 8).

Dystric cambisol (CMd) is the most widespread soil subtype in the cadastral area of Klokočov, where this soil subtype covers $70.68 \%$ of the area (Table 6), unstable slopes are on $26.79 \%$ of the area, which is $18.94 \%$ of the total cadastral area. Eutric leptosol (LPe) covers only $0.93 \%$ of the area, but unstable slopes occur on $62.34 \%$ (only $0.57 \%$ of the total area). In Nová Bystrica cadastre, the most of the slippery slopes is on the eutric cambisol (CMe) $-49.19 \%$ and the skeli-eutric cambisol (CMs) - 13.75\%. The slippery slopes are on $17.11 \%(\mathrm{CMe})$ and $6.00 \%(\mathrm{CMs})$ of the total cadastral area. Similar to Nová Bystrica cadastre, Zákopčie also has the largest representation of unstable slopes on eutric cambisol (CMe) and skeli-eutric cambisol (CMs), which cover 6.06\% 
and $6.32 \%$, respectively, of the total cadastral area. Eutric cambisol (CMe) and stagnic cambisol $(\mathrm{CMj})$ are the main soil subtypes in the cadastral area of Kysucké Nové Mesto, where most of the unstable slopes are located. Unstable slopes cover $29.37 \%$ on the CMe (9.45\% of the total area) and $31.24 \%$ on $\mathrm{CMj}$ (9.17\% of the total area) (Fig. 8).

GSC is represented by quaternary sediments. Cadastral areas of Nová Bystrica, Zákopčie and Kysucké Nové Mesto consist mainly of loamy wastes on flysch rocks (GSC_fs). They cover up to $76.38 \%$ in Nová Bystrica cadastre (unstable slopes within the cadastre are on $28.47 \%$ of the area), in Zákopčie they cover $65.82 \%$ (unstable slopes cover $9.45 \%$ within the cadastral area) and in cadastral area of Kysucké Nové Mesto they cover $57.94 \%$ of the territory (the unstable slopes within the cadastre cover 14.27\%). Loamy wastes on sandstone conglomerates (GSC_sc) form a substantial part of the Klokočov cadastre (58.37\%). Unstable slopes cover $32.07 \%$ of the area (Table 6), which represents $18.71 \%$ of the total cadastral area (Fig. 8).

Coniferous forests (LC_cf) form a substantial part of the landscape cover in all cadastral areas, where the largest areas of unstable slopes are (Table 6). In the Klokočov cadastre, 29.22\% of unstable slopes is in coniferous forests, which represent $18.72 \%$ of the cadastral area. (Fig. 8). In the cadastral area of Nová Bystrica, it is $35.05 \%$ of unstable slopes in coniferous forests $(20.47 \%$ of the cadastral area); in Zákopčie cadastre, it is $18.47 \%$ (7.76\% of the cadastral area); and in the Kysucké Nové Mesto cadastre, it is $29.62 \%$ ( $11.61 \%$ of the cadastral area). An important finding is that in the cadastral area of Klokočov, there is $1 / 3$ of the residential area (LC_r) built on unstable slopes. In Nová Bystrica cadastre, there is $35.41 \%$ of deciduous forests, which are on unstable slopes.

Fig. 8. Occurrence of unstable slopes on selected landscape factors within cadastral areas.

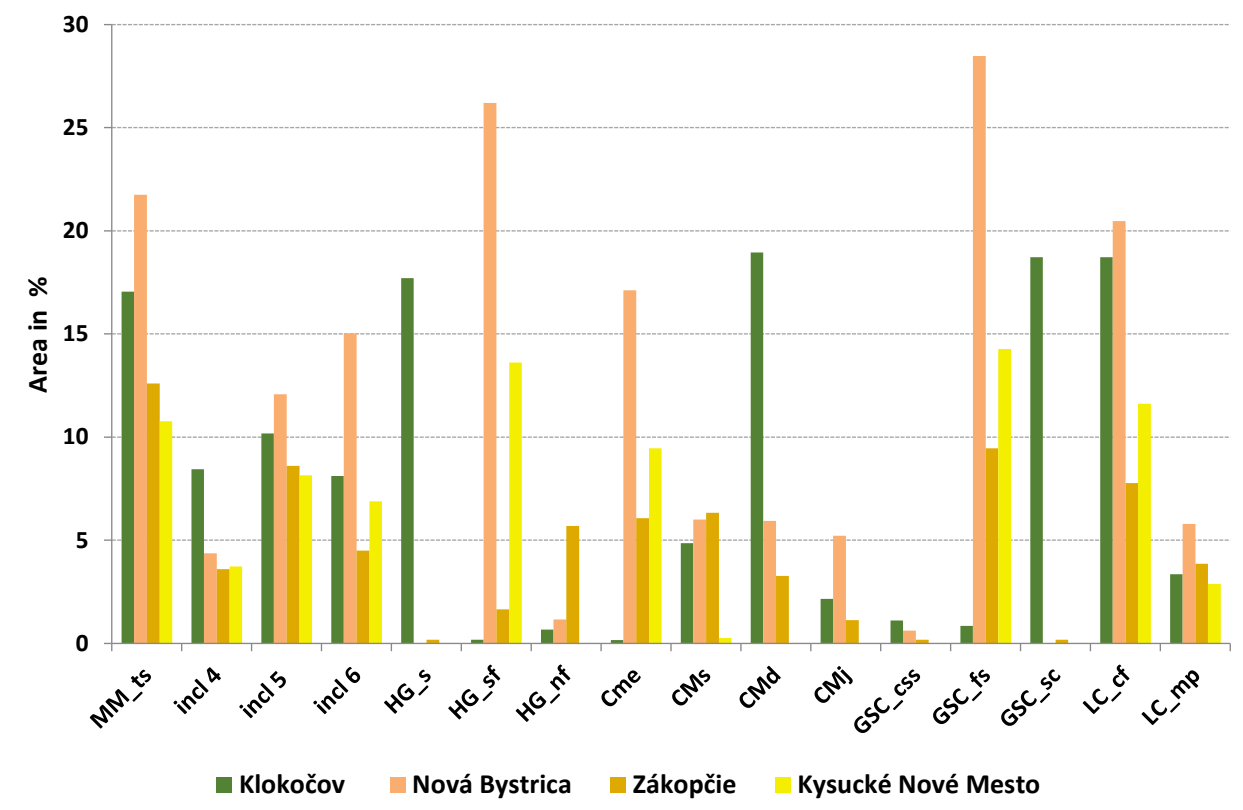




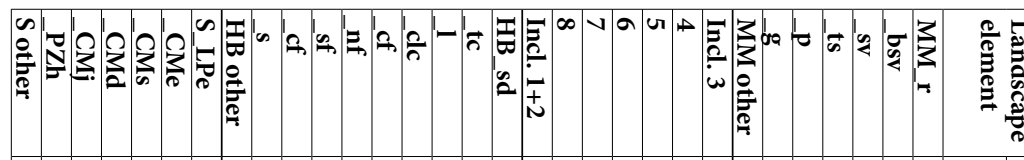

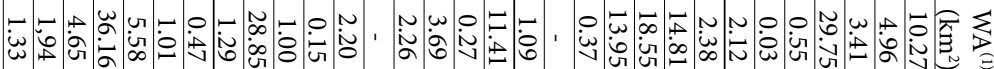

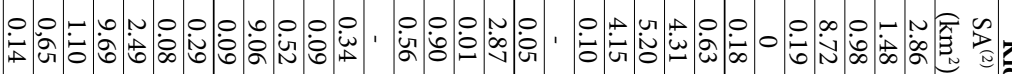

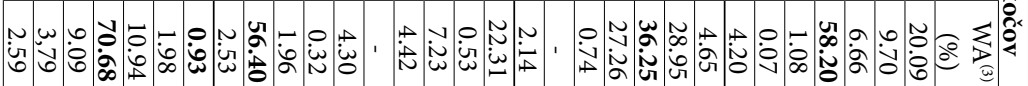

Ð

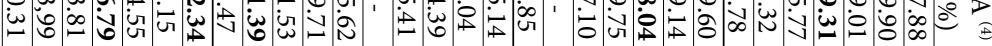

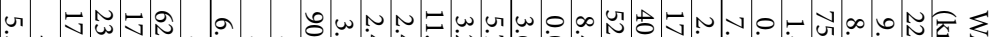

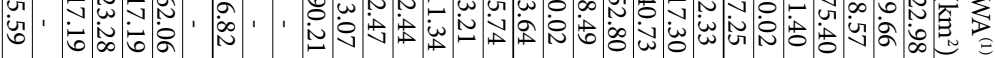

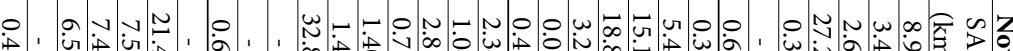

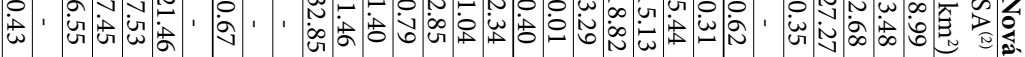

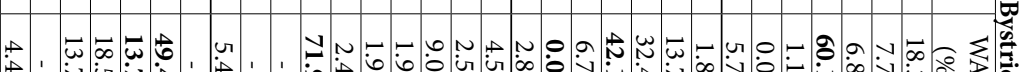

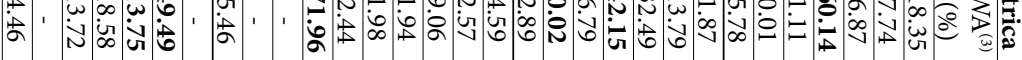

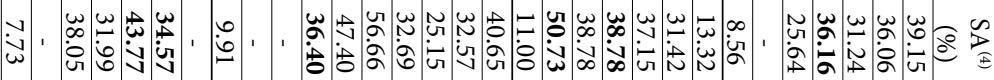

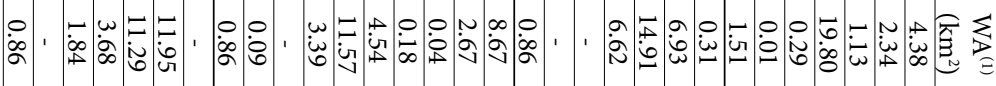

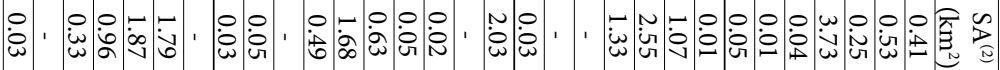

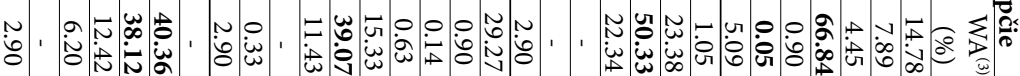

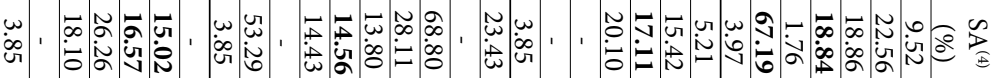

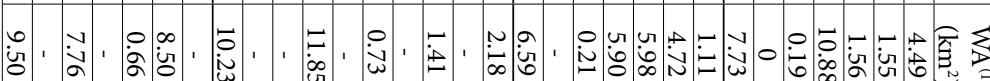

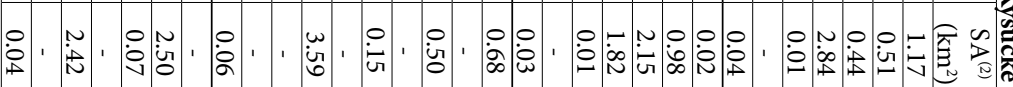

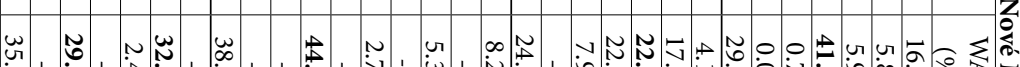

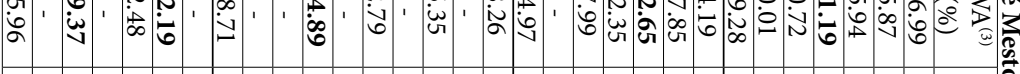

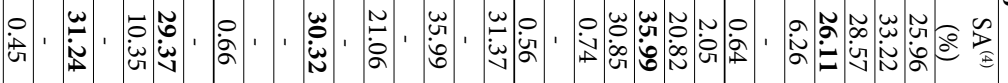




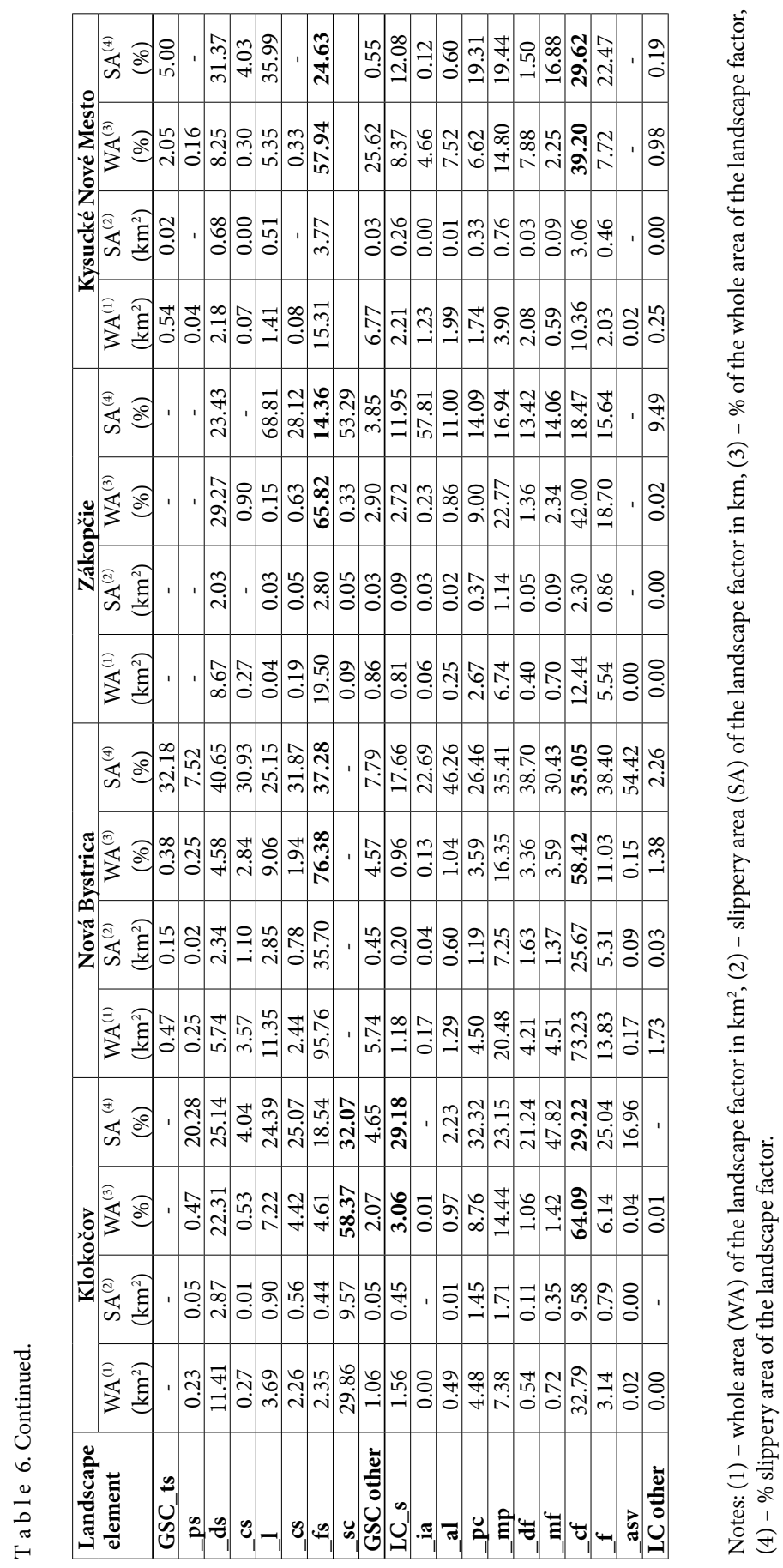




\section{Conclusion}

In order for the stabilization works to be effective, it is necessary to fully know and understand the causes of the development and process of the landslide, to think about the subsequent steps of regulation and to propose a set of measures for permanent territorial protection. The presented work is focused on the quantification of the significance of individual features of the landscape or their combinations, which condition the formation of slope deformations in individual territories and which are to be known before the remediation works start. This knowledge is the starting point before the remediation works, with a logical order of operations according to the urgency. However, each territory is specific with regard to natural or anthropogenic conditions and it is necessary to carry out similar assessment for each territory before the remediation works begin. For areas characteristic by a high occurrence of unstable slopes, it is necessary to quantify their impact on natural factors, thus avoiding the undesirable effects that landslides may have in the area.

\section{Acknowledgements}

The contribution was prepared within the grant project of the Ministry of Education of the Slovak Republic and the Slovak Academy of Sciences No. 2/0078/15 'Ecological optimization of the utilization of landslide areas in selected parts of the flysch zone in regard to the traditional farming.

\section{References}

Ahmadi, H. \& Esfandarani A.T. (2002). Study of effective factors on mass movements (landslide) (case study: Ardal region of Chaharmahale Bakhtiari province). Iranian Journal of Natural Resources, 54(4), 323-329.

Bednarik, M., Clerici, A., Tellini, C. \& Vescovi P. (2005). Using GIS GRASS in evaluation of landslide susceptibility in Termina valley in the Northern Appennines (Italy). In Proceedings of the Conference on Engineering Geology: Forum for young engineering geologists, 6-9 April 2005 (pp. 19-24). Erlangen-Nürnberg: DGGT, Fridrich-Alexander-University.

Blanco, H. \& Lal R. (2008). Principles of soil conservation and management. USA: Springer.

Carrara, A., Cardinali, M., Detti, R., Guzzetti, F., Pasqui, V. \& Reichenbach P. (1991). GIS techniques and statistical models in evaluating landslide hazard. Earth Surface Processes and Landforms, 16(5), 427-445. DOI: 10.1002/ esp.3290160505.

Carrara, A., Cardinali, M., Guzzetti, F. \& Reichenbach, P. (1995). GIS technology in mapping landslide hazard. Geographical Information Systems in Assessing Natural Hazards, 5, 135-175. DOI: 10.1007/978-94-015-8404-3_8.

Diaz, R.P., Sanleandro, M.A., Sanchez, F.B. \& Faulkner H. (2006). The causes of piping in a set of abandoned agricultural terraces in southeast Spain. Catena, 17, 233-245.

Eberhardt, E.K., Thuro, K. \& Luginbuehl M. (2005). Slope instability mechanisms in dipping inter-bedded conglomerates and weathered marls in the 1999 Rufi landslide, Switzerland. Engineering Geology, 77, 35-56. DOI: 10.1016/j. enggeo.2004.08.004

Havlín, A., Bednarik, M. \& Urbanová K. (2009). Assessment of landslide risk in the Silesia-Slovak border-landslides do not respect boundaries (in Czech). In I. Baroň \& J. Klimeš (Eds.), Svahové deformace a pseudokras, 13-15 May 2009 (pp. 1-28). Vsetín: Česká geologická služba, Ústav struktury a mechaniky hornin, AV ČR.

Hazelton, P. \& Murphy B. (2007). Interpreting soil test results. Sydney: CSIRO Press.

Heshmati, M., Arifin, A., Shamshuddin, J., Majid, N.M. \& Ghaituri M. (2011). Factors affecting landslides occurrence in agro-ecological zones in the Merek catchment, Iran. J. Arid Environ., 75, 1072-1082. DOI: 10.1016/j. jaridenv.2011.06.011

Húska, D. (1981). Forest technical meliorations (in Slovak). Nitra: SPU.

Klimeš, J. (2007). Analysis of the conditions of slope deformations in the Vsetínske vrchy Mts (in Czech). Unpublished diploma thesis, Charles University, Prague.

Malík, P., Bačová, N., Hronček, S., Ivanič, B., Káčer, Š., Kočický, D., Maglay, J., Marsina, K., Ondrášik, M., Šefčík, P., Černák, R., Švasta, J. \& Lexa J. (2007). Geological maps compile at a scale of 1:50 000 for the needs of integrated landscape man- 
agement (in Slovak). Bratislava: ŠGÚDŠ.

Magulová, B. (2009). Using GIS for creation of geohazards map as a base for landuse planning (in Slovak). Acta Geologica Slovaca, 1(1), 25-32.

Mazúr, E. \& Lukniš M. (1986). Geomorphological division of SSR and ČSSR. Part Slovakia (in Slovak). Bratislava: Slovenská kartografia.

Morgan, R.P.C. (2005). Soil erosion and conservation. Oxford, London: Blackwell Publisher.

Metelka, V. \& Kycl P. (2007). Mapping of slope landslides susceptibility in GIS environment, Miramar, Kostarika (in Czech). In I. Baroň \& J. Klimeš (Eds.), Svahové deformace a pseudokras, 29-31 May 2007 (pp. 1-15). Vsetín: Česká geologická služba, Ústav struktury a mechaniky hornin, AV ČR.

Ondr, P., Pečenka, J., Polenský, J. \& Ciml J. (2016). Effect of land use changes on water run-off from a small catchment in the Czech Republic. Ekológia (Bratislava), 35, 78-89. DOI: 10.1515/eko-2016-0006.

Pauditš, P. \& Bednarik M. (2002). Using GIS in evaluation of landslide susceptibility in Handlovská kotlina basin. In Proceedings of the 1st European conference on landslide, 24-26 June 2002 (pp. 437-441). Praha: Swets \& Zeitlinger, Lisse.

Pauditš, P., Vlčko, J. \& Jurko J. (2005). Statistic methods in landslide hazard assessment (in Slovak). Mineralia Slovaca, $37(4), 529-538$.

Pauditš, P. \& Bednarik M. (2006). Different interpretations of slope in the statistical evaluation of the landslide hazard (in Slovak). In Geológia a životné prostredie, 14-15 June 2006 (pp. 1-10). Bratislava: ŠGÚDŠ.

Preuth, T., Glade, T. \& Demoulin A. (2010). Stability analysis of a human-influenced landslide in eastern Belgium. Geomorphology, 120 (1-2), 38-47. DOI: 10.1016/j.geomorph.2009.09.013.

Skokanová, H., Faltan, V. \& Havlíček M. (2016). Driving forces of main landscape change processes from past 200 years in central Europe - differences between old democratic and post-socialist countries. Ekológia (Bratislava), 35, 50-65. DOI:10.1515/eko-2016-0004

Šimeková, J. \& Martinčeková, T. et al. (2006). Atlas maps of slope stability of the Slovak Republic (in Slovak) M 1:50000. Záverečná správa. Bratislava: MŽP SR.

Šmilauer, P. \& Lepš J. (2014). Multivariate analysis of ecological data using CANOCO 5. Cambridge: Cambridge University Press.

Societas Pedologica Slovaca (2014). Morphogenetic classification soil system of Slovakia basal reference taxonomy (in Slovak). Bratislava: NPPC - VÚPOP.

Špulerová, J., Drábová, M. \& Lieskovský J. (2016). Traditional agricultural landscape and their management in less favoured areas in Slovakia. Ekológia (Bratislava), 35, 1-12. DOI: 10.1515/eko-2016-0001.

ter Braak C.J.F. \& Šmilauer P. (2012). Canoco 5, Windows release (5.00). Software for multivariate data exploration, testing, and summarization. Wageningen: Biometris, Plant Research International.

Žabková, E., Grenčíková, A., Vrábel, P., Sluka, V., Frličková, M., Molčan, T., Lenková, M., Buček, L. \& Flimmel J. (2003). Kysuca river basin - slope deformation (in Slovak). Geofond. Bratislava: MŽP SR.

Annex 1. Significant landscape parameters $(\mathrm{p}=0.002)$ within the data set of unstable slopes according to the RDA analysis (manual forward selection, 499 permutations).

\begin{tabular}{|l|c|c|c|}
\hline Name & Explained variance (\%) & pseudo-F & P \\
\hline GSC_fs & 6.2 & 840 & 0.002 \\
\hline Zr_prh & 5.9 & 852 & 0.002 \\
\hline HB_t & 5.1 & 786 & 0.002 \\
\hline GSC_1 & 4.2 & 679 & 0.002 \\
\hline HB_1 & 4.2 & 679 & 0.002 \\
\hline GSC_ds & 4.1 & 690 & 0.002 \\
\hline HB_sd & 4.1 & 690 & 0.002 \\
\hline GSC_cs & 3.8 & 672 & 0.002 \\
\hline HB_clc & 3.8 & 710 & 0.002 \\
\hline GSC_css & 3.8 & 710 & 0.002 \\
\hline HB_ac & 3.7 & 730 & 0.002 \\
\hline GSC_sc & 3.7 & 730 & 0.002 \\
\hline
\end{tabular}


Annex 1. Continued.

\begin{tabular}{|c|c|c|c|}
\hline Name & Explained variance (\%) & pseudo-F & $\mathbf{P}$ \\
\hline GSC_ps & 3.7 & 730 & 0.002 \\
\hline Skeleton & 3.0 & 619 & 0.002 \\
\hline LC_cf & 2.6 & 564 & 0.002 \\
\hline S_CMe & 2.4 & 546 & 0.002 \\
\hline LC_mp & 2.3 & 559 & 0.002 \\
\hline HB_sf & 2.3 & 561 & 0.002 \\
\hline GSC_as & 2.2 & 574 & 0.002 \\
\hline GSC_ts & 2.2 & 574 & 0.002 \\
\hline LC_f & 2.1 & 561 & 0.002 \\
\hline HB_l & 2.0 & 579 & 0.002 \\
\hline S_CMs & 2.0 & 592 & 0.002 \\
\hline S_CMj & 1.9 & 588 & 0.002 \\
\hline Soil depth & 1.9 & 615 & 0.002 \\
\hline LC_pc & 1.9 & 641 & 0.002 \\
\hline HB_cf & 1.9 & 672 & 0.002 \\
\hline HB_nf & 1.9 & 672 & 0.002 \\
\hline LC_mf & 1.9 & 708 & 0.002 \\
\hline $\mathrm{Zr} \_\mathrm{h}$ & 1.8 & 742 & 0.002 \\
\hline LC_op & 1.8 & 786 & 0.002 \\
\hline LC_df & 1.8 & 834 & 0.002 \\
\hline LC_ia & 1.8 & 890 & 0.002 \\
\hline Zr_pih & 1.8 & 957 & 0.002 \\
\hline LC_wa & 1.8 & 1035 & 0.002 \\
\hline HB_dc & 1.8 & 1126 & 0.002 \\
\hline HB_tc & 1.8 & 1126 & 0.002 \\
\hline LC_asv & 1.8 & 1232 & 0.002 \\
\hline LC_r & 1.8 & 1232 & 0.002 \\
\hline S_CMs & 1.8 & 1365 & 0.002 \\
\hline HB_cf & 1.8 & 1528 & 0.002 \\
\hline HB_s & 1.8 & 1528 & 0.002 \\
\hline S_CMe & 1.8 & 1717 & 0.002 \\
\hline Zr_ih & 1.8 & 1980 & 0.002 \\
\hline $\mathrm{Zr} \_\mathrm{ph}$ & 1.8 & 1980 & 0.002 \\
\hline S_FLe & 1.8 & 2315 & 0.002 \\
\hline S_GLe & 1.7 & 2686 & 0.002 \\
\hline S_LPk & 1.6 & 3222 & 0.002 \\
\hline S_LPe & 1.6 & 4214 & 0.002 \\
\hline DGL & 1.5 & 5873 & 0.002 \\
\hline S_CMj & 1.1 & 6449 & 0.002 \\
\hline Inclination & 1.0 & 10966 & 0.002 \\
\hline S_CMd & 0.7 & 21180 & 0.002 \\
\hline S_PZh & 0.4 & 15352 & 0.002 \\
\hline
\end{tabular}

